\title{
IDENTIFIKASI DAN ASPEK EKOLOGI KERANG TRIDACNINAE DI PERAIRAN SEKITAR PULAU VENU, KABUPATEN KAIMANA, PROVINSI PAPUA BARAT ${ }^{1}$
}

\author{
Identification and Ecological Aspects of Tridacninae \\ in the Shallow Waters of Venu Island, District Kaimana, West Papua
}

\author{
Defy N Pada ${ }^{2}$, Farnis B Boneka ${ }^{3}$, Gustaf F Mamangkey ${ }^{3}$
}

\begin{abstract}
Giant clams (Bivalvia, Cardiidae) or usually called tridacnid clams are marine organisms that live in the Indo Pacific coral reef ecosystems. Tridacnids are known to have high economic values as food, and their shells can be used for jewelries and decorations. Today, seven tridacnid species were listed in the IUCN Red List. Moreover, all tridacnid species are included in the appendices II of CITES. This research was aimed to identify the numbers of tridacnid species, to describe the ecological aspects through density index, species relative density and biodiversity index, and to assess the effectiveness of conservation effort in Venu Island and the surrounding waters. Survey was conducted in September 2012 at 5 sites, using belt transect method. A $100 \mathrm{~m}$ transect was laying in the reef edge in 5 and 10 meter depths. The results showed, there were four species of tridacnids found in this area, Tridacna crocea, T. gigas, T. maxima and T. squamosa. $T$. crocea has the highest density index and species relative density both in 5 and 10 meter depths ( $5 \mathrm{~m}$ depth $\mathrm{K}=0,030 ; \mathrm{KR}=81,081 \% ; 10 \mathrm{~m}$ depth $\mathrm{K}=0,021 ; \mathrm{KR}=41,176 \%$ ). The waters arround Venu Island were categorized as moderate biodiversity, since the value of biodiversity index is between 1 and 3 $\left(H^{\prime}=2,239\right)$. Most of tridacnids found in this area lived in coral massive $(46,6 \%)$ and rock substrates $(30,7 \%)$. The result of interview showed that the conservation efforts are not effective enough.
\end{abstract}

Keywords : marine ecology, biodiversity, Tridacnid, Venu Island

\section{ABSTRAK}

Kima raksasa (Bivalvia, Cardiidae) yang biasa disebut dengan kerang Tridacninae adalah organisme laut yang hidup di ekosistem terumbu karang di wilayah Indo-Pasifik. Kerang Tridacninae dikenal memiliki nilai ekonomi yang penting, karena selain sebagai sumber makanan, cangkangnya dapat dijadikan sebagai bahan dekorasi dan perhiasan. Saat ini sebanyak tujuh spesies kerang Tridacninae masuk dalam daftar merah dari International Union for Conservation of Nature and Natural Resources (IUCN redlist for threathened species). Bahkan semua spesies kerang Tridacninae telah masuk dalam Lampiran II dari Convention on International Trade of Endangered Species (CITES). Tujuan dari penelitian ini adalah untuk mengetahui jenis kerang Tridacninae di perairan sekitar Pulau Venu Kabupaten Kaimana, untuk mendeskripsikan beberapa aspek

\footnotetext{
${ }^{1}$ Bagian dari skripsi

${ }^{2}$ Mahasiswa Program Studi IImu Kelautan FPIK-UNSRAT

${ }^{3}$ Staf pengajar Fakultas Perikanan dan IImu Kelautan Universitas Sam Ratulangi
} 
ekologi kerang Tridacninae melalui indeks ekologi yakni kepadatan (K), kepadatan relatif spesies $(K R)$, dan indeks keanekaragaman $\left(H^{\prime}\right)$, serta untuk melihat efektivitas upaya konservasi yang dilakukan di Pulau Venu terutama terhadap keberadaan kerang Tridacninae. Kegiatan penelitian dilakukan pada bulan September 2012, pada 5 stasiun penelitian, dengan menggunakan metode transek sabuk (belt transek), sepanjang 100 meter pada kedalaman 5 meter dan 10 meter. Hasil penelitian menunjukkan bahwa terdapat 4 spesies kerang Tridacninae di perairan sekitar Pulau Venu, yaitu T. crocea, T. gigas, T. maxima, dan $T$. squamosa. Nilai kepadatan dan kepadatan relatif spesies tertinggi di dua kedalaman adalah $T$. crocea (kedalaman 5 meter $\mathrm{K}=0,030 ; \mathrm{KR}=81,081 \%$; kedalaman 10 meter $\mathrm{K}=0,021 ; \mathrm{KR}=41,176 \%$ ). Perairan sekitar Pulau Venu berkategori keanekaragaman sedang, karena memiliki nilai indeks keanekaragaman diantara 1 dan 3 (rata-rata $H^{\prime}=2,239$ ). Sebagian besar kerang Tridacninae yang ditemukan hidup pada substrat karang masif $(46,6 \%)$ dan batuan $(30,7 \%)$. Saat ini upaya konservasi yang dilakukan di perairan sekitar Pulau Venu dirasakan belum cukup efektif.

Kata kunci : ekologi laut, keanekaragaman, Tridacninae, Pulau Venu

\section{PENDAHULUAN}

Kima raksasa (Bivalvia, Cardiidae) adalah moluska laut yang hidup di ekosistem terumbu karang di wilayah Indo-Pasifik. Hewan ini memiliki dua genera (Tridacna dan Hippopus) dengan sembilan spesies, di mana tujuh spesies di antaranya ditemukan di perairan Indonesia. Secara geografis, kerang ini memiliki distribusi terbatas di wilayah tropis Indo-Pasifik, dari Red Sea sampai ke Kepulauan Pasifik Tuamotu (Yusuf et al., 2009). Kerang Tridacninae tinggal pada daerah dangkal di ekosistem terumbu karang, dan hidup bersimbiosis dengan alga fotosintetik zooxanthellae (Anonim, 2012), pada kedalaman 1-20 meter (Jantzen et al., 2008 dalam Hernawan 2011). Dari segi ekologis kerang Tridacninae merupakan biota yang berperan sebagai biofilter alami, di mana mereka mampu menyaring amonia dan nitrat terlarut dalam air laut untuk kebutuhan zooxanthellae akan nitrogen bagi proses pertumbuhannya (Braley 2009). Kerang Tridacninae mendapatkan sebagian besar makanan (70-100\%) dari alga simbiotik zooxanthellae, dan sisanya dengan cara menyaring atau "filter feeding" (Anonim, 2012).

Kerang Tridacninae dikenal memiliki nilai ekonomi yang penting karena selain sebagai sumber makanan, cangkangnya dapat dijadikan sebagai bahan dekorasi dan perhiasan. Selain itu juga, kerang ini banyak dicari orang untuk perhiasan serta untuk industri ubin teraso, sehingga populasinya makin berkurang (Nontji, 2002). Hal ini membuat keberadaannya menjadi terancam di alam. Perairan laut di wilayah Distrik Buruway Kabupaten Kaimana Provinsi Papua Barat, termasuk dalam bagian segitiga karang dunia. Hasil penilaian cepat (Marine Rapid Assessment) tahun 2006 yang dilakukan oleh Conservation International $(\mathrm{Cl})$, bekerja sama dengan Ditjen PHKA melalui BKSDA Papua II serta Universitas Negeri Papua (UNIPA), serta beberapa kegiatan penelitian lainnya yang pernah dilakukan, menunjukkan bahwa kawasan ini memiliki potensi sumberdaya dan keanekaragaman hayati laut yang tinggi. Di wilayah ini (dan di sebagian besar wilayah Papua), kerang tridacnid bukan saja dimanfaatkan sebagai sumber protein, tetapi juga sebagai penghasil kapur alami yang dimakan bersama 
sirih dan pinang, sebagaimana tradisi sebagian besar masyarakat di Papua.

Informasi ilmiah untuk jenis-jenis kerang Tridacninae di wilayah Kabupaten Kaimana, Papua Barat khususnya di perairan sekitar Pulau Venu, belum banyak dilakukan, oleh karena itu kegiatan penelitian ini bertujuan untuk mengidentifikasi jenis-jenis kerang Tridacninae, melakukan kajian ekologi yang meliputi kepadatan, kepadatan relatif spesies dan indeks keanekaragaman, serta untuk melihat efektivitas upaya konservasi yang dilakukan di wilayah ini, terutama terhadap keberadaan kerang Tridacninae.

\section{METODE}

Penelitian dilakukan di perairan sekitar Pulau Venu, Kabupaten Kaimana, Provinsi Papua Barat. Lokasi penelitian sebanyak 5 stasiun, di mana 3 stasiun diambil di sekitar daerah terumbu karang Pulau Venu dan 2 stasiun diambil pada gosong terumbu (patch reef) yang letaknya berdekatan dengan Pulau Venu (Gambar 1).

Pengambilan data menggunakan metode Line Intercept Transect (LIT) yang dimodifikasi, yang dinamakan transek sabuk (Belt Transect). Pada setiap stasiun pengambilan data, digunakan roll transek sepanjang 100 meter, yang diletakkan di daerah terumbu karang pada kedalaman 5 dan 10 meter. Setiap stasiun hanya menggunakan 1 transek sepanjang 100 meter. Observasi dilakukan dengan jarak 2,5 meter ke kiri dan 2,5 meter ke kanan sepanjang transek, sehingga total area yang disurvey adalah 1000 $\mathrm{m}^{2}$ di mana $500 \mathrm{~m}^{2}$ pada kedalaman 5 meter dan $500 \mathrm{~m}^{2}$ pada kedalaman 10 meter (Yusuf $d k k, 2009$ ). Daerah yang menjadi lokasi penelitian sebelumnya telah dilakukan survey awal, dan penentuan titik sampling dilakukan dengan menggunakan GPS. Pengukuran parameter fisik perairan dilakukan dengan cara mengukur suhu, salinitas dan tingkat kecerahan air laut.
Dua orang penyelam bertugas untuk membentangkan transek. Setelah transek diletakkan kemudian dilanjutkan dengan melakukan pengambilan data untuk tiap-tiap transek, cara terbaik untuk melakukan ini dengan menempatkan 2 orang pengamat pada tiap satu transek, yang menyusuri tali transek pada bagian kiri dan kanan, sehingga setiap pengamat mendapat bagian $250 \mathrm{~m}^{2}$ untuk tiap transek. Proses identifikasi dilakukan secara in situ, di mana setiap kerang tridacnid yang ditemukan dicatat jenis dan jumlahnya, serta diambil gambarnya dengan menggunakan kamera bawah air. Substrat tempat kerang tridacnid hidup juga dicatat dengan menggunakan kode bentik berdasarkan English et al. (1997).

Data hasil penelitian dianalisis dan disajikan dalam bentuk tabel dan grafik. Kepadatan $(\mathrm{K})$, kepadatan relatif (KR) dan indeks keanekaragaman $\left(\mathrm{H}^{\prime}\right)$ dihitung berdasarkan Krebs (1999). Indeks Keanekaragaman ( $\left.\mathrm{H}^{\prime}\right)$ dihitung menggunakan rumus ShannonWienner melalui persamaan :

Di mana:

$$
\mathbf{H}^{\prime}=-\sum(n i / N \ln n i / N),
$$

$\mathrm{H}^{\prime}=$ Indeks keanekaragaman

Shannon-Wienner

$n i=$ Jumlah individu suatu jenis

$\mathrm{N}=$ Total seluruh individu

Data mengenai substrat tempat hidup kerang Tridacninae disajikan dalam persentase, berdasarkan kategori substrat. Efektivitas upaya konservasi dinilai berdasarkan data jumlah dan ukuran individu kerang Tridacninae yang ditemukan, serta data pembanding dari hasil wawancara singkat dengan masyarakat lokal yang biasa beraktifitas di perairan sekitar Pulau Venu, Kabupaten Kaimana.

\section{HASIL DAN PEMBAHASAN}

\section{Jenis Kerang Tridacninae}

Hasil penelitian menunjukkan bahwa total jumlah individu kerang Tridacninae yang tercatat sebanyak 88 individu, dari empat spesies, yaitu 
Tridacna crocea, $T$. maxima, $T$. squamosa dan $T$. gigas. Jumlah spesies kerang Tridacninae yang ditemukan di wilayah ini lebih dari setengah jumlah spesies kerang Tridacninae yang ada di Indonesia, di mana di Indonesia ditemukan tujuh spesies kerang Tridacninae. Dibandingkan dengan perairan Kepulauan Seribu (Yusuf et al. 2009) dan Pulau Bunaken (Mambu, 2012) yang masing-masing hanya memiliki tiga spesies, perairan sekitar Pulau Venu memiliki spesies kerang Tridacninae yang lebih banyak.

\section{Kepadatan (K) dan Kepadatan Relatif Spesies (KR)}

Hasil analisis data menunjukkan bahwa $T$. crocea memiliki kepadatan dan kepadatan relatif spesies yang lebih besar dari spesies lain. T. crocea juga lebih banyak ditemukan baik pada kedalaman 5 meter $(81,081 \%)$ maupun kedalaman 10 meter $(41,176 \%)$. Tabel 1 menyajikan secara lengkap nilai Kepadatan dan Kepadatan Relatif spesies kerang Tridacninae pada setiap kedalaman, sedangkan grafik yang menggambarkan tentang nilai kepadatan dan kepadatan relatif spesies disajikan dalam Gambar 2 dan 3.

\section{Indeks Keanekaragaman ( $\left.H^{\prime}\right)$}

Hasil penelitian menunjukkan bahwa kedalaman 10 meter $\left(H^{\prime}=2,594\right)$ di semua stasiun memiliki indeks keanekaragaman $\left(H^{\prime}\right)$ yang paling tinggi, dibanding dengan kedalaman 5 meter $\left(H^{\prime}=1,882\right)$. Nilai Indeks keanekaragaman spesies kerang Tridacninae pada Stasiun 1 hingga Stasiun 5, menunjukkan bahwa daerah ini memiliki kategori keanekaragaman sedang, ditandai dengan nilai $H^{\prime}$ antara 1 sampai 3 (rata-rata H' pada kedalaman 5 dan 10 meter $=2,239$ ). Gambar 4 menyajikan grafik tentang Indeks Keanekaragaman Kerang Tridacninae.

\section{Parameter Fisik di Lokasi Penelitian \\ Pengukuran parameter fisik perairan dilakukan untuk melihat pengaruh faktor-faktor fisik air laut.}

Hasil pengukuran menunjukkan bahwa suhu air laut di semua lokasi penelitian berkisar antara $29-30^{\circ} \mathrm{C}$, dengan ratarata $29,6^{\circ} \mathrm{C}$. Salinitas berkisar antara 30-32 ppm dengan rata-rata 30,6 ppm, sedangkan tingkat kecerahan air laut berkisar antara 12-18 meter, dengan rata-rata kecerahan 15,2 meter (Tabel 2). Nilai dari parameter fisik yang terukur di lokasi pengambilan data menunjukkan bahwa daerah ini memiliki kondisi fisik perairan yang cukup baik (Mambu 2012), di mana pada kisaran tersebut, ekosistem terumbu karang dapat tumbuh dengan optimal. Ini tentunya dapat memberikan pengaruh yang baik terhadap pertumbuhan kerang Tridacninae.

Sebagian besar kerang Tridacninae yang ditemukan di perairan sekitar Pulau Venu hidup pada substrat karang masif (CM) (terutama $T$. crocea), sedangkan karang mati (DC) merupakan tipe substrat yang memiliki persentase paling rendah. T. maxima sebagian besar hidup pada substrat batuan (RCK), namun demikian kerang ini juga dapat ditemukan pada tipe substrat karang masif dan karang mati (Yusuf et al. 2009 dan Hernawan 2011). T. gigas sebagian besar hidup pada substrat pasir, namun ada juga yang hidup pada substrat patahan karang (Rb) (Calumpong 1992 dalam Yusuf et al. 2009). Sedangkan $T$. squamosa, kebanyakan hidup pada substrat patahan karang dan juga pada daerah berpasir (Yusuf et al. 2009). Secara umum kerang Tridacninae di perairan sekitar Pulau Venu hidup pada substrat karang masif $(46,6 \%)$ dan batuan $(30,7 \%)$. Hal ini dapat terjadi karena pada kedua jenis substrat ini hidup $T$. crocea dan $T$. maxima yang merupakan jenis yang paling banyak ditemukan. Hal ini juga terkait dengan sifat dari $T$. crocea dan $T$. maxima yang membenamkan sebagian atau seluruh cangkangnya ke dalam substrat (Mambu, 2012). Persentase tipe substrat yang menjadi tempat hidup dari kerang Tridacninae disajikan dalam Gambar 5. 


\section{Persepsi Warga Tentang Daerah Konservasi}

Data hasil wawancara dengan

beberapa masyarakat Kampung Adijaya yang melakukan aktivitas di perairan sekitar Pulau Venu menunjukkan bahwa sebagian besar masyarakat mengkonsumsi jenis kerang Tridacninae sebagai sumber makanan. Selain itu, sebagian besar dari responden juga menyatakan bahwa mereka jarang mengambil kerang Tridacninae ini (Gambar 6).

$$
\text { Cangkang dari kerang }
$$

Tridacninae ini dimanfaatkan sebagai bahan pembuat kapur. Hasil wawancara menunjukkan pula bahwa populasi kerang Tridacninae di wilayah ini sudah mulai berkurang jika dibandingkan dengan waktu-waktu sebelumnya. Rata-rata responden menyebutkan bahwa penurunan populasi kerang Tridacninae diakibatkan oleh kegiatan eksploitasi yang sebagian besar dilakukan oleh nelayan-nelayan luar Kaimana yang mengambil sumberdaya laut secara ilegal. Sebagian besar responden menyatakan bahwa keberadaan Kawasan Konservasi Perairan Daerah (KKPD) Kabupaten Kaimana cukup bermanfaat untuk melindungi sumberdaya alam laut yang mereka miliki. Hal ini sejalan dengan hasil penelitian yang pernah dilakukan oleh Pada et al. (2011) dan Sulistyaningrum (2011).

Walaupun demikian, dari hasil analisis data wawancara didapatkan bahwa pengelolaan konservasi kawasan dirasakan belum cukup efektif. Hal ini disebabkan oleh beberapa hal :

1. Jarak yang cukup jauh dari pusat pemerintahan Kaimana, menyebabkan kurangnya pengawasan dari instansi terkait;

2. Sosialisasi dan proses penyadaran masyarakat akan pentingnya konservasi masih belum merata;

3. Rencana zonasi KKPD Kaimana belum tersosialisasi dengan baik;

4. Legalitas hukum penetapan kawasan yang yang belum cukup kuat untuk melakukan penegakkan hukum.
Masyarakat di wilayah ini memiliki kearifan lokal dalam menjaga sumberdaya alamnya, melalui tradisi sasi. Tradisi sasi ini biasanya dilakukan secara parsial dan temporal berdasarkan marga, pada suatu wilayah laut tertentu. Namun karena lemahnya pengawasan terhadap sumberdaya alam, mengakibatkan penurunan kualitas, populasi dan keanekaragaman hayati tetap terjadi (DKP Kaimana, 2011)

\section{KESIMPULAN}

Wilayah perairan sekitar Pulau Venu, Kabupaten Kaimana memiliki empat jenis kerang Tridacninae, yaitu Tridacna crocea, $T$. maxima, $T$. squamosa, dan $T$. gigas. $T$. crocea merupakan jenis kerang Tridacninae yang memiliki kepadatan dan kepadatan relatif yang tertinggi. Indeks keanekaragaman $\left(H^{\prime}\right)$ di wilayah ini memiliki kategori keanekaragaman sedang, karena memiliki nilai $\mathrm{H}^{\prime}$ antara 1 dan 3.

Hasil pengukuran parameter fisik perairan menunjukkan bahwa wilayah perairan sekitar Pulau Venu baik untuk pertumbuhan kerang Tridacninae. Sebagian besar kerang Tridacninae yang hidup di wilayah perairan sekitar Pulau Venu memiliki tipe substrat karang masiv dan batuan. Upaya konservasi yang dilakukan di wilayah perairan sekitar Pulau Venu belum cukup efektif.

\section{UCAPAN TERIMA KASIH}

Penulis ingin menyampaikan ucapan terima kasih kepada Pemerintah Daerah Kabupaten Kaimana, masyarakat Kampung Adijaya, serta nelayan-nelayan yang beraktifitas di perairan sekitar Pulau Venu. Ucapan terima kasih juga disampaikan kepada Pimpinan dan Staff dari Conservation International Indonesia Kaimana Program, yang telah membantu dan menyediakan fasilitas pendukung selama kegiatan penelitian berlangsung. 


\section{DAFTAR PUSTAKA}

Anonim. 2012. Tridacna (genus). Http://zipcodezoo.com. (Dikunjungi pada tanggal 28 April 2012).

Braley, R. D. 2009. Giant clam biology and culture. http://aquasearch.com. (Dikunjungi pada tanggal 28 April 2012).

Dinas Kelautan dan Perikanan Kabupaten Kaimana. 2011. Data Dasar Potensi Sumberdaya Perikanan Kabupaten Kaimana. Dinas Perikanan dan Perikanan bekerjasama dengan Conservation International Indonesia. Kaimana

English, S., Wilkinson, C., dan Baker, V. 1997. Survey Manual For Tropical Marine Resources. $2^{\text {nd }}$ Edition. Australian Institute of Marine Science. Townsville.

Hernawan, U. E. 2011. Taxonomy of Indonesian Giant Clams (Cardiidae, Tridacninae). Bonorowo Wetlands.

Krebs, C. J. 1999. Ecological Methodology. Harper Collins Publishers. Columbia.
Mambu, R. S. 2012. Studi Beberapa Aspek Ekologis Kerang Tridacnidae di Pulau Bunaken. FPIK, UNSRAT.

Nontji, A. 2002. Laut Nusantara. Djambatan. Jakarta.

Pada, D.N., Fauzan, A. Y., dan Sulistyaningrum, W. 2011. Persepsi Masyarakat di Kawasan Konservasi Laut Daerah Kabupaten Kaimana, Indonesia. Conservation International Indonesia. Kaimana.

Sulistyaningrum, W. 2012. Laporan hasil survey KAP (Knowledge, Atitude and Practice) Masyarakat Teluk Triton, Kabupaten Kaimana. RARE Indonesia dan Conservation International Indonesia. Kaimana.

Yusuf, C., Ambariyanto, dan Hartati, R. 2009. Abundance of Tridacna (Family Tridacnidae) at Seribu Islands and Manado Waters, Indonesia. Jurnal IImu Kelautan Universitas Diponegoro (UNDIP). Semarang. Vol. 14.

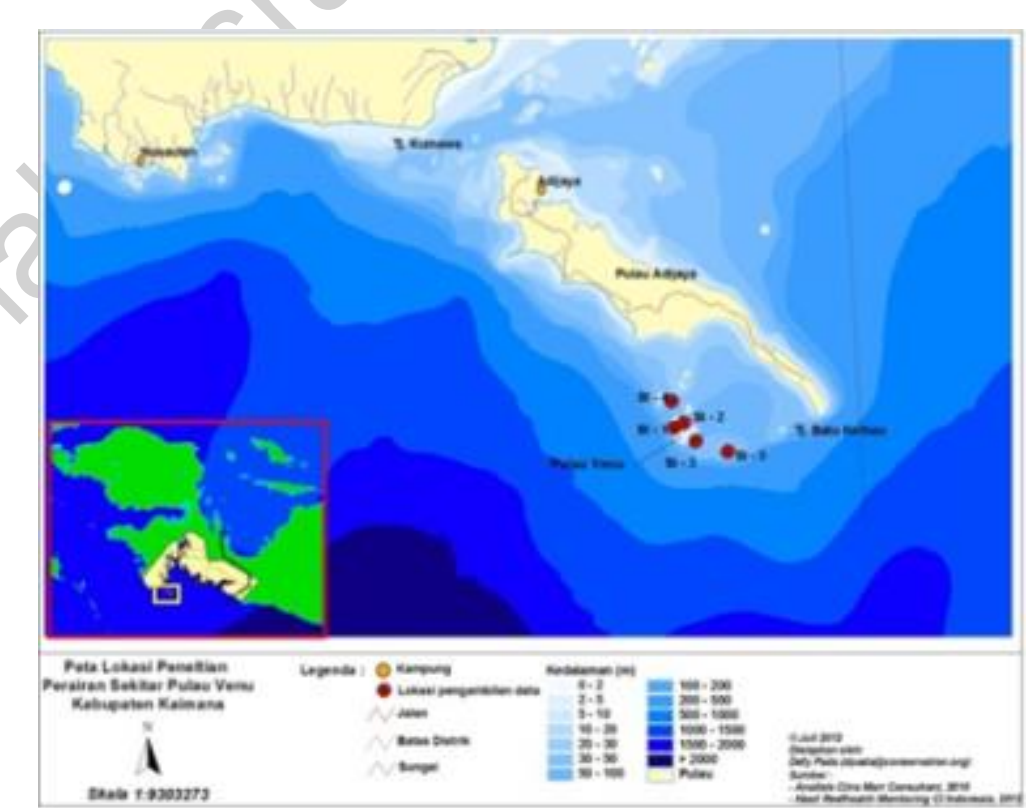

Gambar 1. Lokasi penelitian di perairan sekitar Pulau Venu, Kabupaten Kaimana, Provinsi Papua Barat. 


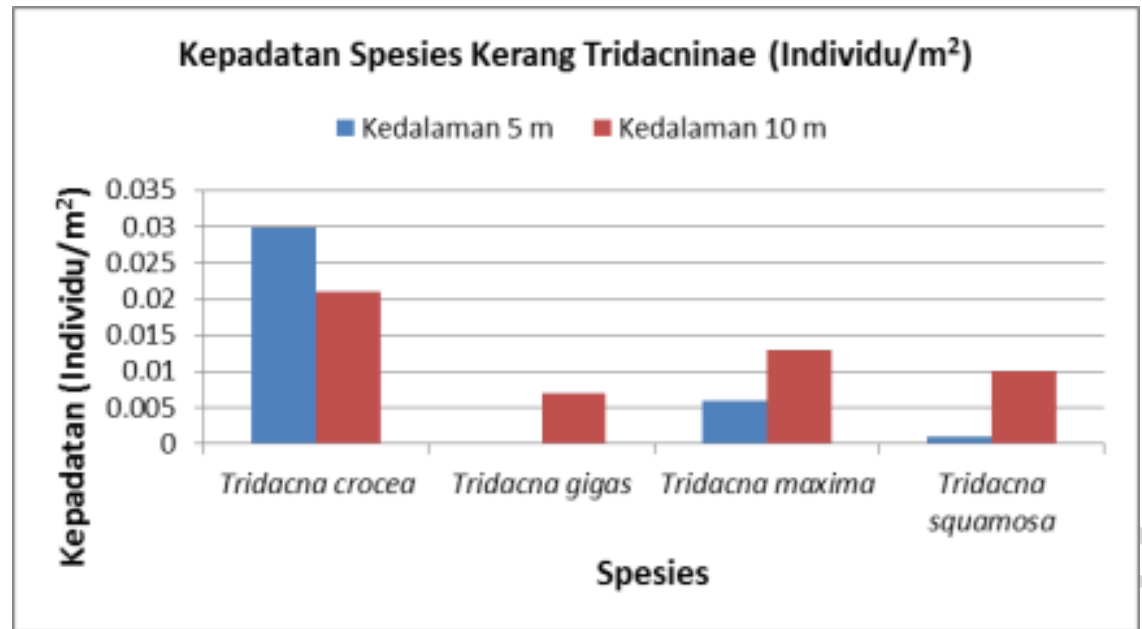

Gambar 2. Kepadatan Spesies Kerang Tridacninae

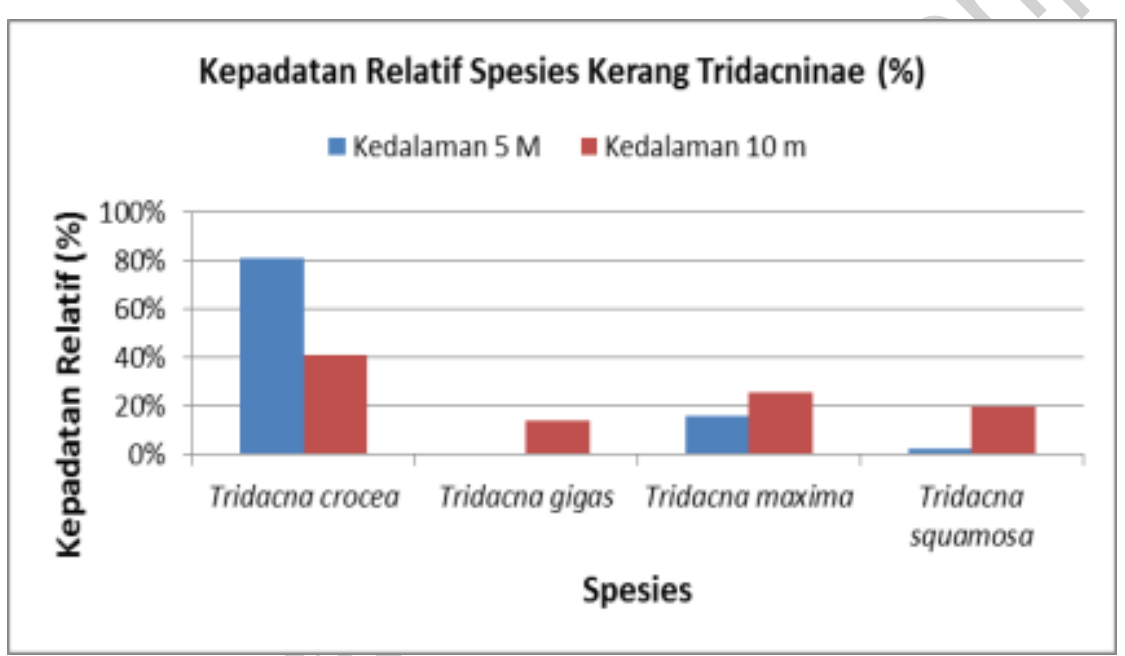

Gambar 3. Kepadatan Relatif Spesies Kerang Tridacninae

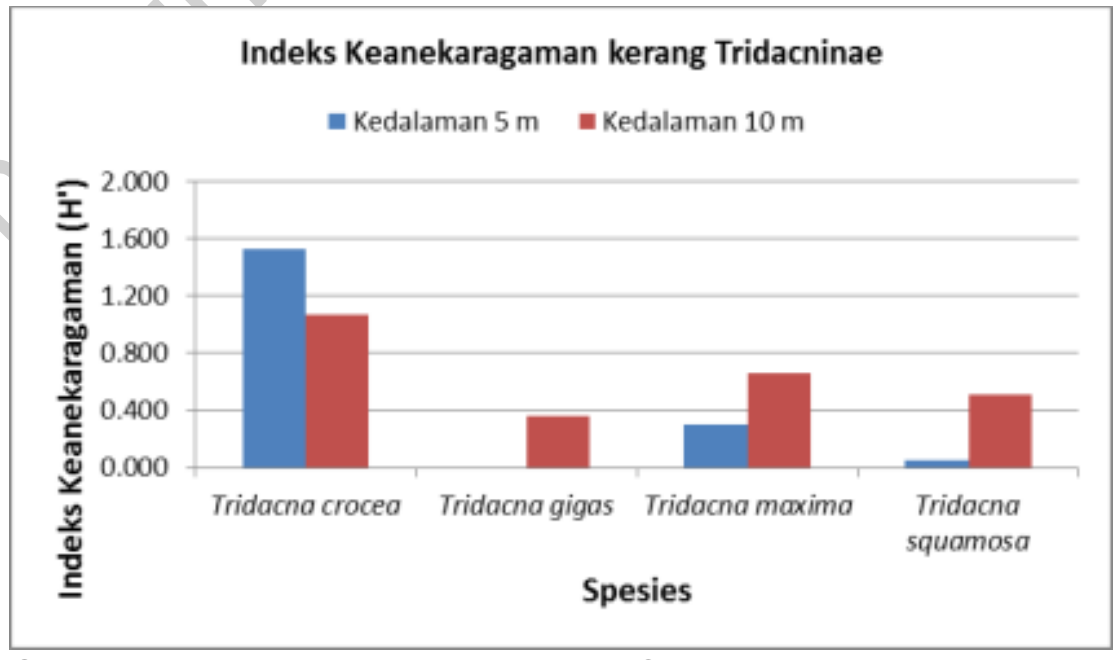

Gambar 4. Indeks Keanekaragaman Spesies Kerang Tridacninae 


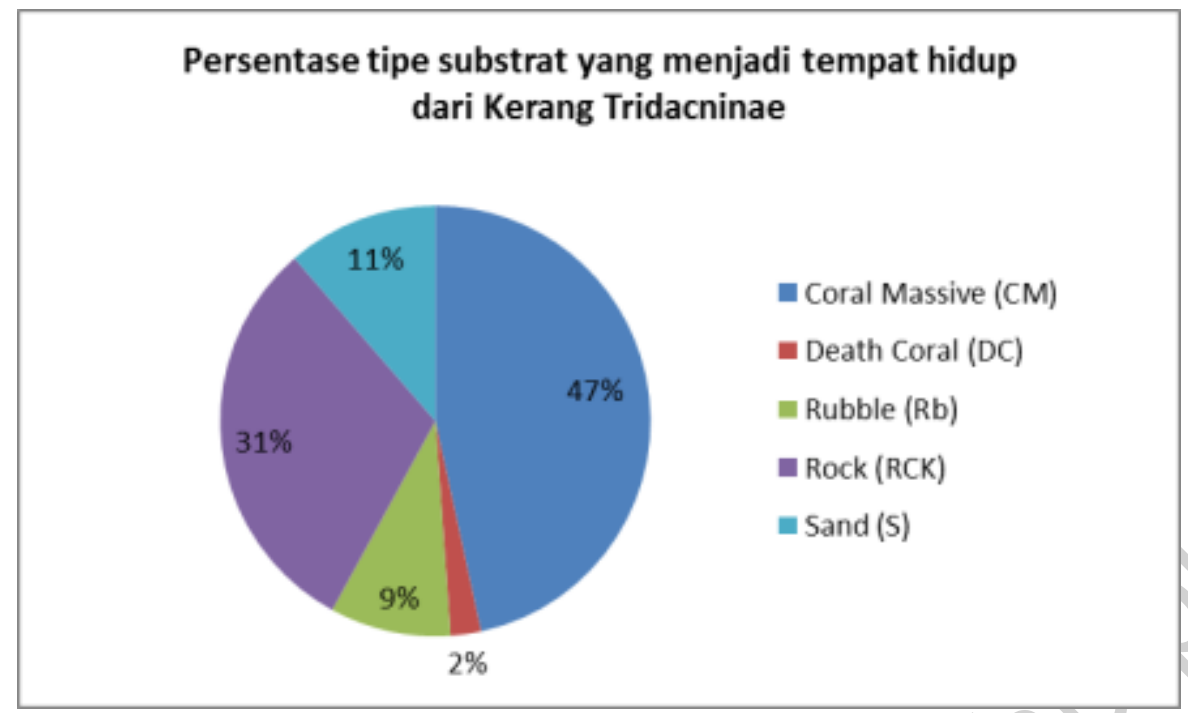

Gambar 5. Persentase tipe substrat yang menjadi tempat hidup dari kerang Tridacninae

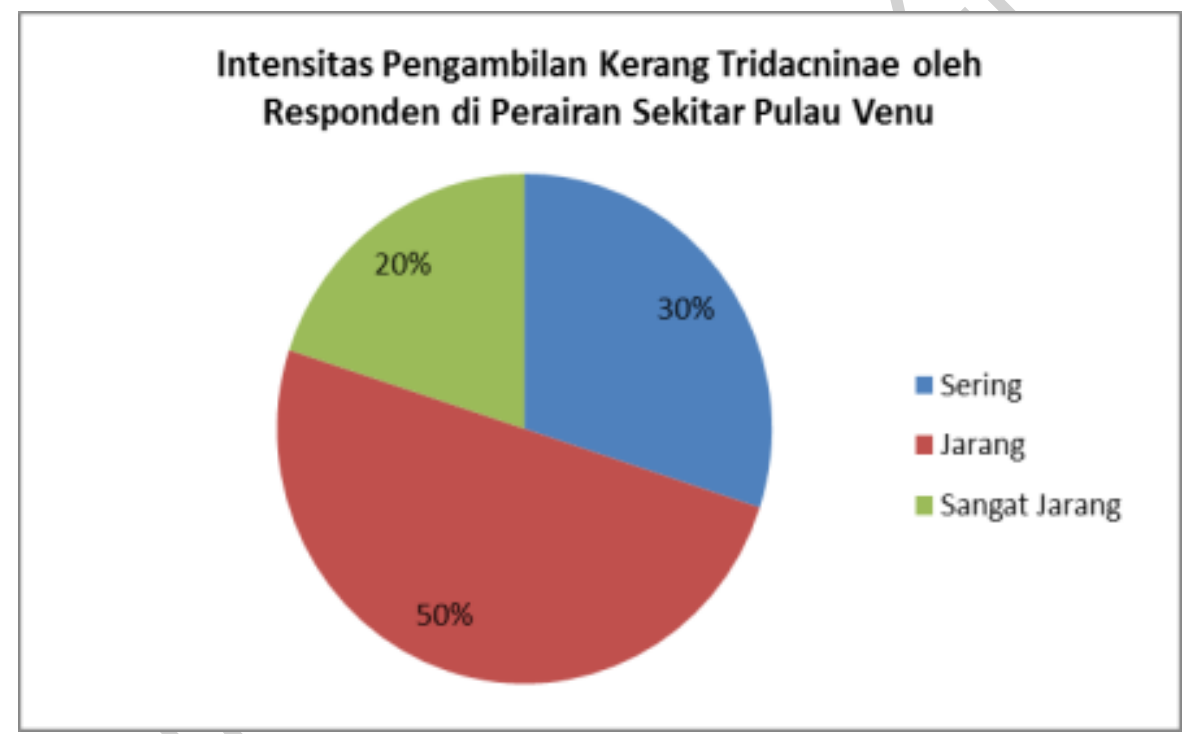

Gambar 6. Intensitas pengambilan kerang Tridacninae oleh responden.

Tabel 1. Kepadatan (K) dan Kepadatan Relatif Spesies (KR) Kerang Tridacninae

\begin{tabular}{|l|c|c|c|c|}
\hline \multirow{2}{*}{ Spesies } & \multicolumn{2}{|c|}{ Kedalaman $\mathbf{5 ~} \mathbf{c}$} & \multicolumn{2}{c|}{ Kedalaman $\mathbf{1 0} \mathbf{~ m}$} \\
\cline { 2 - 5 } & $\mathbf{K}\left(\mathbf{i n d} / \mathbf{m}^{\mathbf{2}}\right)$ & $\mathbf{K R}(\%)$ & $\mathbf{K}\left(\mathbf{i n d} / \mathbf{m}^{\mathbf{2}}\right)$ & $\mathbf{K R} \mathbf{\%})$ \\
\hline T. crocea & 0,030 & 81,081 & 0,021 & 41,176 \\
\hline T. gigas & 0,000 & 0,000 & 0,007 & 13,725 \\
\hline T. maxima & 0,006 & 16,216 & 0,013 & 25,490 \\
\hline T. squamosa & 0,001 & 2,703 & 0,010 & 19,608 \\
\hline \multicolumn{1}{|c|}{ Total } & $\mathbf{0 , 0 3 7}$ & $\mathbf{1 0 0 \%}$ & $\mathbf{0 , 0 5 1}$ & $\mathbf{1 0 0 \%}$ \\
\hline
\end{tabular}


Tabel 2. Hasil pengukuran parameter fisik di lokasi penelitian

\begin{tabular}{|c|c|c|c|c|}
\hline Stasiun & Tanggal & Suhu $\left({ }^{\circ} \mathbf{C}\right)$ & Salinitas (ppm) & Kecerahan $(\mathbf{m})$ \\
\hline 1 & 5 -Sep-12 & 29 & 30 & 12 \\
\hline 2 & 6 -Sep-12 & 30 & 30 & 14 \\
\hline 3 & 6 -Sep-12 & 30 & 30 & 15 \\
\hline 4 & $7-S e p-12$ & 29 & 32 & 18 \\
\hline 5 & 7-Sep-12 & 30 & 31 & 17 \\
\hline
\end{tabular}

